\title{
Genotype-phenotype associations between chymase and angiotensin-converting enzyme gene polymorphisms in chronic systolic heart failure patients
}

Ruthie E. Amir, $M D^{1}$, Offer Amir, MD', Hagar Paz, $R N^{2}$, Moran Sagiv, MPE ${ }^{1}$, Roi Mor, MSc ${ }^{1}$, Michael Sagiv, PhD ${ }^{1}$, and Basil S. Lewis, MD, PRCP 2,3

\begin{abstract}
Purpose: Angiotensin II, which plays a crucial role in the myocardial remodeling process of heart failure, is generated via the angiotensin-converting enzyme and chymase pathways. We studied angiotensin-converting enzyme and chymase-1 polymorphisms in patients with systolic heart failure and the correlation with clinical status and left ventricular function. Methods: We genotyped 195 patients with heart failure and systolic left ventricular dysfunction (ejection fraction $<40 \%$ ) for angiotensin-converting enzyme insertion (I)/deletion (D) and chymase-1 $(-1903 \mathrm{G} / \mathrm{A})$ polymorphisms. Heart failure etiology and patients' clinical manifestations were analyzed in relation to genotype subtypes. Results: The chymase-1 -1903 GG genotype was associated with a nonischemic heart failure etiology $\left(\chi^{2}=6.67, P=0.009\right)$. In the group of heart failure patients, the odds ratio of chymase-1 GG genotype having a nonischemic etiology was 2.48 (95\% Cl 1.23-5.00). The chymase-1 GG genotype was associated with lower ejection fraction $(P=0.005)$. Conversely, the angiotensin-converting enzyme $\mathrm{D}$ allele had no detectable impact on systolic heart failure phenotype. Conclusions: In patients with chronic systolic heart failure, the chymase-1 polymorphism was related to nonischemic etiology of heart failure. Patients homozygous for the $G$ allele had a significantly greater reduction in systolic left ventricular function. Genet Med 2008:10(8):593-598.
\end{abstract}

Key Words: heart failure, renin-angiotensin-aldosterone system, chymase, polymorphisms, angiotensin-convertingenzyme, insertion/deletion

The renin-angiotensin-aldosterone system (RAAS) plays a major role in the pathogenesis of heart failure (HF), including myocardial remodeling, ${ }^{1}$ regulation of blood pressure, and vascular smooth muscle growth and proliferation. ${ }^{2}$ In the human heart, angiotensin II is produced from angiotensin I by angiotensin-converting enzyme (ACE) and the heart chymase (CMA) pathways. Human heart chymase is a chymotrypsinlike serine protease that is the most catalytically efficient enzyme described, thus far, for the cleavage of angiotensin I to angiotensin II. ${ }^{3}$ Angiotensin II is primarily (80\%) generated via the chymase pathway. ${ }^{4}$ Heart chymase has been implicated in the

From the ${ }^{I}$ Department of Genetics and Molecular Biology, Zinman College of Physical Education and Sport Sciences at the Wingate Institute, Netanya, Israel; ${ }^{2}$ Heart Failure Center, Department of Cardiovascular Medicine, Lady Davis Carmel and Lin Medical Centers, Haifa, Israel; and ${ }^{3}$ Ruth and Bruce Rappaport School of Medicine, Technion-Israel Institute of Technology, Haifa, Israel.

Ruthie Amir, MD, Department of Genetics and Molecular Biology, Zinman College of Physical Education and Sports Sciences at the Wingate Institute, Netanya, 42902, Israel. E-mail: ruthiea@wincol.ac.il.

The first two authors contributed equally.

Disclosure: The authors declare no conflict of interest.

Submitted for publication February 3, 2008.

Accepted for publication May 7, 2008.

DOI: $10.1097 / G I M .0 b 013 e 3181804 b 9 c$ process of acute inflammation, ${ }^{5}$ apoptosis of cardiac myocytes, proliferation of fibroblasts ${ }^{6}$ and tissue remodeling. . $^{7-9}$

There is growing evidence of a genetic contribution to the pathophysiology of HF. ${ }^{10}$ To assess the importance of ACE and chymase pathways on the development and phenotypic expression of cardiomyopathy and HF disease; we studied two candidate polymorphisms in the genes encoding these two enzymes. A functional polymorphism of the human ACE gene (GenBank accession no. AF118569) was described in which the presence (insertion: I allele), rather than the absence (deletion: D allele), of a 287-bp Alu repeat element in intron 16 (rs4646994) is associated with lower enzyme activity. ${ }^{11,12}$ In a review of the literature, Bleumink et al. ${ }^{13}$ recognized the debatable data in the literature regarding the significance of ACE I/D polymorphism in heart failure. In several different ethnic groups, whites, Chinese, black South Africans, and Japanese, there was no association with either ischemic or nonischemic cardiomyopathy. ${ }^{13}$ On the contrary, a very few studies did suggest an association between the DD genotype and transplantfree survival rates. Interestingly this poor outcome associated with the genetic polymorphism was blunted with beta blocker treatment. ${ }^{14}$ The adverse impact of the DD genotype was also demonstrated in a Swedish population study, but only in concert with several other polymorphisms and not by itself. ${ }^{15}$ The 
second polymorphism which we studied is involved in the same enzymatic step of Angiotensin I conversion to Angioten$\sin$ II. The localization of this novel single nucleotide polymorphism (SNP) (G/A transition at position - 1903 of the $5^{\prime}$ untranscribed region of the gene, rs1800875) close to the regulatory region of the CMA1 gene (GenBank accession no. M64269) makes it a plausible candidate for HF clinical syndrome. However, there is an impressive shortage of data in the literature regarding the impact of this specific polymorphism on systolic HF. On the basis of the premise that ACE I/D and CMA1 (-1903G/A) may affect RAAS activity, we hypothesized that these polymorphisms may have clinical importance in patients with chronic systolic HF. We evaluated these two polymorphisms of the ACE/CMA1 genes for their prevalence among chronic systolic HF patients compared with healthy controls and their relation to the etiology (ischemic/nonischemic) of HF. We also examined the association of these gene polymorphisms with the clinical manifestations of our HF patients.

\section{MATERIALS AND METHODS}

\section{Study population}

We used a case-control design to study 195 consecutive HF patients followed in our specialized HF center and 200 population control subjects. Controls [165 (82.5\%) males and 35 (17.5\%) females, age $26 \pm 4$ years] were all healthy individuals who had no history of or treatment for coronary artery disease, diabetes mellitus, hypertension, or hypercholesterolemia. The study and control groups were all Israeli residents with an equivalent ratio of non-Ashkenazi and Ashkenazi descent (2:1). The HF patients had symptomatic systolic HF (echocardiographic left ventricular $[\mathrm{LV}]$ ejection fraction $<40 \%$ ) for at least 3 months before recruitment. Etiology of HF was classified as ischemic or nonischemic, based on a history or not of myocardial infarction and/or coronary angiography, which were in keeping with the findings of reduced LV systolic function. Clinical and laboratory data were recorded and blood samples were obtained for genotypic analysis. Patients were followed over a period of 30 months, or up to an end point of death. The study was approved by the Institution Review Board (Helsinki committee) of the Lady Davis Carmel Medical Center, and all patients gave written informed consent before inclusion in the study.

\section{Genotyping for ACE and CMA1 polymorphisms}

Genomic DNA was extracted from peripheral blood leukocytes using a standard protocol. ${ }^{16}$ Genotyping of the ACE I/D polymorphism was performed using polymerase chain reaction (PCR) according to the method of Lindpaintner et al. ${ }^{17}$ Genotyping for the CMA1 1903G/A polymorphism was conducted using the polymerase chain reaction-restriction fragment length polymorphism approach, as described by Pfeufer et al. ${ }^{18}$ PCR fragments were amplified from $\sim 20 \mathrm{ng}$ of each DNA sample used as a template in $20 \mu \mathrm{L}$ PCRs containing 0.2 $\mathrm{U}$ Taq polymerase, $1 \times$ concentration PCR buffer, $0.2 \mathrm{mmol} / \mathrm{L}$ of each dNTP, and 10 pmol of each of the following primers:
GGAAATGTGAGCAGATAGTGCAGT (CMA1-sense) and AATCCGGAGCTGGAGAACTCTTGTC (CMA1-antisense), and GCCCTGCAGGTGTCTGCAGCATGT (ACE-sense) and GGATGGCTCTCCCCGCCTTGTCTC (ACE-antisense). The initial denaturation at $95^{\circ} \mathrm{C}$ for 5 minutes was followed by 35 cycles of $94^{\circ} \mathrm{C}$ for 30 seconds, $56-58^{\circ} \mathrm{C}$ annealing for $30 \mathrm{sec}-$ onds, and $65^{\circ} \mathrm{C}$ elongation for 45 seconds. ACE I/D genotypes were designated as follows: I/I, a single band of 597-bp; D/I, two bands of 319- and 597-bp; and D/D, a single band of 319bp. Because the $\mathrm{D}$ allele in heterozygous samples is preferentially amplified, there is a tendency to misclassify the ACE I/D genotype as the $\mathrm{D} / \mathrm{D}$ genotype. To avoid this misclassification, a second PCR was performed using I-specific primers: TGGGACCACAGCGCCCGCCACTAC (I-specific-sense) and TCGCCAGCCCTCCCATGCCCATAA (I-specific -antisense). This PCR yields a 335-bp fragment only in the presence of the I allele, and no product in a sample homozygous for the $D$ allele. The CMA1 PCR fragments (285-bp length) were digested with $10 \mathrm{U}$ of restriction endonuclease Bst XI in the supplied buffer (New England Biolabs, MA) for 2 hours at $55^{\circ} \mathrm{C}$. The $-1903 \mathrm{~A}$ allele lacks a Bst XI site present in the $-1903 \mathrm{G}$ allele, so $-1903 \mathrm{~A}$ alleles are detected as uncut fragments of $285-\mathrm{bp}$ whereas the $-1903 \mathrm{G}$ alleles are detected as Bst XI fragments of 195 and 90-bp. Genotyping was performed by experienced staff. PCR scores by two independent investigators who were blind to subject data, correlated well $(\mathrm{R} 2=0.991)$.

\section{Data analysis}

The SPSS statistical package version 13.0 was used for statistical evaluation (SPSS Inc., Chicago, IL). A $\chi^{2}$ test was used to confirm that observed genotype frequencies were in HardyWeinberg equilibrium and to compare the genotype frequencies between patients and controls. Genotype subtypes comparisons were made by analysis of variance and the Kruskal-Wallis test (asymmetrical data distribution). Continuous variables were compared by genotypes group by linear analysis of variance. Stepwise multiple linear regression analysis was used to evaluate whether the number of ACE and CMA1 alleles carried by each patient had statistical influence on clinical and laboratory parameters. Asymmetrically distributed variables were log transformed before regression analysis. Continuous data are presented as mean $\pm \mathrm{SD}$. Square multiple correlation coefficients $\left(R^{2}\right)$ were calculated. To adjust for multiple comparisons, $P$ values were considered significant if $<0.01$.

\section{RESULTS}

The clinical characteristics of the patients are summarized in Table 1 . They were aged $64 \pm 13$ years, $162(83 \%)$ were males. The etiology of HF was ischemic heart disease in $124(64 \%)$ patients, 105 (54\%) gave a history of or were treated for hypertension, 77 (39\%) for diabetes mellitus. Atrial fibrillation was present in $63(32 \%)$ patients and the mean QRS on the surface electrocardiogram was $137 \pm 45.5$ milliseconds. Mean echocardiographic LV end-diastolic dimension was $6.2 \pm 0.8 \mathrm{~cm}$ and ejection fraction (EF) $24 \pm 6.5 \%$. Treatment included 
Table 1

Patients clinical characteristics

\begin{tabular}{|c|c|c|c|}
\hline Clinical characteristics & All patients $(\mathrm{n}=195)$ & Ischemic etiology $(\mathrm{n}=124)$ & Nonischemic etiology $(\mathrm{n}=71)$ \\
\hline Age (yrs) & $64 \pm 13$ & $68 \pm 11$ & $59 \pm 14$ \\
\hline Sex (male/female) & $162(83 \%) / 33(17 \%)$ & $162(83 \%) / 33(17 \%)$ & $51(72 \%) / 20(28 \%)$ \\
\hline NYHA $\geq$ III (\%) & $105(54 \%)$ & $69(56 \%)$ & $36(51 \%)$ \\
\hline Systemic hypertension (\%) & $105(54 \%)$ & $75(60 \%)$ & $30(42 \%)$ \\
\hline Diabetes mellitus (\%) & $77(39 \%)$ & $58(47 \%)$ & $19(27 \%)$ \\
\hline Atrial fibrillation (\%) & $63(32 \%)$ & $39(31 \%)$ & $24(34 \%)$ \\
\hline \multicolumn{4}{|l|}{ Medication (n/\%) } \\
\hline$\beta$-Blockers & $167(87 \%)$ & $108(87 \%)$ & $59(83 \%)$ \\
\hline ACE-I +/or ARB & $181(93 \%)$ & $114(92 \%)$ & $67(94 \%)$ \\
\hline Aldosterone antagonists & $56(29 \%)$ & $37(29 \%)$ & $19(27 \%)$ \\
\hline BP systolic (mm Hg) & $114 \pm 24$ & $112 \pm 23$ & $117 \pm 25$ \\
\hline LV end-diastolic dimension $(\mathrm{cm})$ & $6.2 \pm 0.8$ & $6.2 \pm 0.8$ & $6.2 \pm 0.8$ \\
\hline LV ejection fraction (\%) & $24 \pm 6.5$ & $25 \pm 6.5$ & $22 \pm 6.2$ \\
\hline QRS duration (ms) & $137 \pm 45.5$ & $134 \pm 40.1$ & $143 \pm 53.5$ \\
\hline Serum creatinine $(\mathrm{mg} / \mathrm{dL})$ & $1.35 \pm 0.6$ & $1.44 \pm 0.7$ & $1.18 \pm 0.4$ \\
\hline Creatinine clearance $(\mathrm{mL} / \mathrm{min})$ & & $61.0 \pm 26.0$ & $78.8 \pm 34.2$ \\
\hline Serum urea $(\mathrm{mg} / \mathrm{dL})$ & & $67.8 \pm 38.2$ & $54.6 \pm 38.1$ \\
\hline Mortality (\%) & & $12(10 \%)$ & $5(7 \%)$ \\
\hline
\end{tabular}

ACE inhibitor and/or angiotensin II receptor blockers in 181 (93\%) patients, direct aldosterone antagonists in 56 (29\%) patients, and beta blockers in $167(87 \%)$ patients. Patients were all considerably disabled and 105 (54\%) were in Functional Class 3 or 4 (New York Heart Association, NYHA). Over the course of follow-up, there were 17 (9\%) deaths, 9 due to HF and 2 due to fatal arrhythmia.

The data on allele and genotype frequencies in patients and controls are shown in Table 2. For both ACE I/D and CMA1 $-1903 \mathrm{G} / \mathrm{A}$ polymorphisms, there was no deviation from Hardy-Weinberg equilibrium in either the HF patients group (all) (allele frequency ACE I/D $=0.38 / 0.62$, expected genotype frequencies $\% \mathrm{II} / \mathrm{ID} / \mathrm{DD}=14 \% / 47 \% / 39 \%, \chi^{2}=0.60, P=0.74$; allele frequency CMA1 A/G $=0.53 / 0.47$, expected genotype frequencies $\% \mathrm{AA} / \mathrm{AG} / \mathrm{GG}=28 \% / 50 \% / 22 \%, \chi^{2}=0.25, P=$ 0.87 ), the ischemic HF patients group (allele frequency $A C E$ $\mathrm{I} / \mathrm{D}=0.36 / 0.64$, expected genotype frequencies $\% \mathrm{II} / \mathrm{ID} / \mathrm{DD}=$ $13 \% / 46 \% / 41 \%, \chi^{2}=0.20, P=0.90$; allele frequency $C M A 1$ $\mathrm{A} / \mathrm{G}=0.57 / 0.43$, expected genotype frequencies $\% \mathrm{AA} / \mathrm{AG} /$ $\left.\mathrm{GG}=32.5 \% / 49 \% / 18.5 \%, \chi^{2}=1.08, P=0.58\right)$, the nonischemic HF patients group (allele frequency ACE I/D $=0.42 / 0.58$, expected genotype frequencies $\% \mathrm{II} / \mathrm{ID} / \mathrm{DD}=17 \% / 49 \% / 34 \%$, $\chi^{2}=0.47, P=0.78$; Allele frequency CMA1 A/G $=0.46 / 0.54$, expected genotype frequencies $\%$ AA/AG/GG $=21 \% / 50 \% /$ $29 \%, \chi^{2}=0.11, P=0.94$ ), or the control group (allele frequency $A C E \mathrm{I} / \mathrm{D}=0.33 / 0.67$, expected genotype frequencies $\%$ $\mathrm{II} / \mathrm{ID} / \mathrm{DD}=11 \% / 44 \% / 45 \%, \chi^{2}=0.38, P=0.82$; Allele frequency $C M A 1 \mathrm{~A} / \mathrm{G}=0.48 / 0.52$, expected genotype frequen-
Table 2

Genotype frequencies of CMA1 - 1903G/A and ACE I/D polymorphisms in HF patients

\begin{tabular}{lcccc}
\hline Genotype & \multicolumn{3}{c}{$\mathrm{n}(\%)$} & \\
\cline { 2 - 4 } CMA1 -1903G/A & $\mathrm{AA}$ & $\mathrm{AG}$ & $\mathrm{GG}$ & Significance \\
\hline HF-all (195) & $52(27)$ & $102(52)$ & $41(21)$ & ${ }^{a} P=0.28 ; \chi^{2}=2.52$ \\
$\begin{array}{l}\text { Ischemic } \\
\quad \text { HF (124) }\end{array}$ & $36(29)$ & $69(56)$ & $19(15)$ & \\
$\begin{array}{l}\text { Non-Ischemic } \\
\quad \text { HF (71) }\end{array}$ & $16(23)$ & $33(46)$ & $22(31)$ & ${ }^{b} P=0.03 ; \chi^{2}=6.71$ \\
controls (200) & $40(20)$ & $112(56)$ & $48(24)$ & \\
$\begin{array}{l}\text { ACE I/D } \\
\text { Patients (195) }\end{array}$ & $32(16)$ & $85(44)$ & $78(40)$ & ${ }^{a} P=0.12 ; \chi^{2}=4.21$ \\
$\begin{array}{l}\text { Ischemic } \\
\quad \text { HF (124) }\end{array}$ & $18(14)$ & $54(44)$ & $52(42)$ & \\
$\begin{array}{l}\text { Nonischemic } \\
\quad \text { HF (71) }\end{array}$ & $14(20)$ & $31(43)$ & $26(37)$ & ${ }^{b} P=0.58 ; \chi^{2}=1.06$ \\
controls (200) & $19(10)$ & $93(46)$ & $88(44)$ & \\
\hline
\end{tabular}

Allele frequency CMA1 A/G (0.53/0.47) in patients (all) vs. controls $(0.48 /$ $0.52)\left(P=0.17 ; \chi^{2}=1.83\right)$, allele frequency CMA1 A/G $(0.57 / 0.43)$ in ischemic vs. nonischemic patients $(0.46 / 0.54)\left(P=0.03 ; \chi^{2}=4.44\right)$; allele frequency $A C E \mathrm{I} / \mathrm{D}(0.38 / 0.62)$ in patients (all) vs. controls $(0.33 / 0.67)(P=$ $\left.0.10 ; \chi^{2}=2.56\right)$, allele frequency $A C E \mathrm{I} / \mathrm{D}(0.36 / 0.64)$ in ischemic vs. nonischemic patients $(0.42 / 0.58)\left(P=0.30 ; \chi^{2}=1.05\right)$.

${ }^{a}$ Significance of genotype frequencies in patients (all) vs, controls.

${ }^{b}$ Significance for genotype frequencies in ischemic vs. nonischemic patients. 
cies $\% \mathrm{AA} / \mathrm{AG} / \mathrm{GG}=23 \% / 50 \% / 27 \%, \chi^{2}=1.45, P=0.48$ ). The subjects' age, gender distribution, and Ashkenazi/nonAshkenazi ancestry did not differ by either ACE I/D or CMA1 $-1903 \mathrm{G} / \mathrm{A}$ genotypes. For both ACE I/D and CMAI $-1903 \mathrm{G} / \mathrm{A}$ polymorphisms, frequencies from dbSNP, using data for mixed European or white populations, show similarities to our data. Allele (and genotype) frequencies of the whole cohort of HF patients were similar to that among healthy controls (Table 2). However, CMA1 -1903G/A allele and genotype frequencies of the nonischemic patients differed significantly from those of ischemic patients (Table 2). Moreover, comparison of HF etiology by CMA1 genotype revealed that the CMA1 - 1903GG genotype was associated with nonischemic HF etiology (Fig. 1, Tables 2 and $3, \chi^{2}=6.67, P=0.009$ ). The odds ratio for the CMA1 GG genotype in nonischemic patients was 2.48 (95\% CI 1.23-5.00). Importantly, ACE I/D polymorphism was not associated with HF etiology in our patients.

To determine genotype-phenotype correlations, we compared patients' clinical characteristics between genotype subtypes of each polymorphism. Compared with the AA and AG genotype subgroup, homozygous CMA1 GG patients had lower values of left ventricular ejection fraction $(P=0.005)$ (Table 3). Multivariate stepwise linear regression, adjusted for age, previous myocardial infarction, NYHA class, echocardiographic LV dimension and QRS duration on the surface electrocardiogram, showed that CMA1 GG genotype (after echocardiographic LV dimension) was the most powerful independent predictor of reduced systolic function (adjusted odds ratio $32.6,95 \%$ CI $11.9-89.3, P=0.0007)$. The ACE D allele was not associated with the phenotypic expression of HF in our patients. It should be noted that no difference was found in clinical disability (NYHA class) and mortality in regard to either CMA1 or ACE gene polymorphism.

\section{DISCUSSION}

The study showed that in patients with chronic systolic HF, the CMA1 -1903G/A polymorphism, and in particular homozygosity for the $\mathrm{G}$ allele, was more frequent in patients with a nonischemic etiology of HF and was associated with a greater

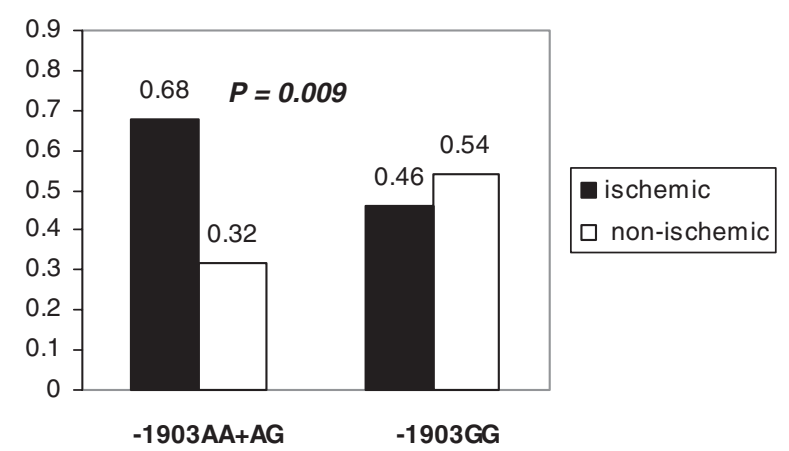

Fig. 1. Heart failure (HF) etiology (ischemic vs. nonischemic) by CMA1 - 1903G/A genotype. AA, homozygous for the -1903 A allele; AG, heterozygous; GG, homozygous for the $-1903 \mathrm{G}$ allele.
Table 3

Clinical characteristics in relation to CMA1 genotype

\begin{tabular}{|c|c|c|c|}
\hline $\begin{array}{l}\text { Clinical } \\
\text { characteristics }\end{array}$ & $\begin{array}{c}\mathrm{AA}+\mathrm{AG} \\
\text { genotype }(\mathrm{n}=154)\end{array}$ & $\begin{array}{l}\text { GG genotype } \\
(\mathrm{n}=41)\end{array}$ & $P$ \\
\hline Age (yrs) & $65 \pm 13$ & $60 \pm 13$ & $0.02 \mathrm{~S}$ \\
\hline Sex (male/female) & $130(84 \%) / 24(16 \%)$ & $32(78 \%) / 9(22 \%)$ & 0.33 \\
\hline NYHA class $\geq \mathrm{III}$ & $86(56 \%)$ & $19(46 \%)$ & 0.27 \\
\hline Ischemic etiology & $105(68 \%)$ & $19(46 \%)$ & 0.009 \\
\hline Systemic hypertension & $89(58 \%)$ & $19(46 \%)$ & 0.18 \\
\hline Diabetes mellitus & $61(39 \%)$ & $17(42.5 \%)$ & 0.81 \\
\hline Atrial fibrillation & $53(34 \%)$ & $10(24 \%)$ & 0.22 \\
\hline $\begin{array}{l}\text { Previous myocardial } \\
\text { infarction (\%) }\end{array}$ & $91(59 \%)$ & $23(56 \%)$ & 0.69 \\
\hline $\begin{array}{l}\text { Previous coronary } \\
\text { bypass surgery }\end{array}$ & $52(34 \%)$ & $15(36 \%)$ & 0.78 \\
\hline \multicolumn{4}{|l|}{ Medication (n/\%) } \\
\hline$\beta$-Blocker & $134(87 \%)$ & $36(87.5 \%)$ & 0.91 \\
\hline ACE-I +/or ARB & $142(92 \%)$ & $39(96 \%)$ & 0.76 \\
\hline Aldosterone antagonist & $45(29 \%)$ & $11(27.5 \%)$ & 0.83 \\
\hline BP systolic (mm Hg) & $115 \pm 24$ & $110 \pm 20$ & 0.24 \\
\hline $\begin{array}{l}\text { LV end-diastolic } \\
\text { dimension }(\mathrm{cm})\end{array}$ & $6.2 \pm 0.8$ & $6.2 \pm 0.7$ & 0.90 \\
\hline LV ejection fraction (\%) & $25 \pm 6.5$ & $21 \pm 6.1$ & 0.005 \\
\hline QRS duration (ms) & $141 \pm 48$ & $125 \pm 33$ & 0.02 \\
\hline Serum creatinine $(\mathrm{mg} / \mathrm{dL})$ & $1.3 \pm 0.5$ & $1.4 \pm 0.9$ & 0.53 \\
\hline $\begin{array}{l}\text { Creatinine clearance } \\
\qquad(\mathrm{mL} / \mathrm{min})\end{array}$ & $66.4 \pm 0.0$ & $70.3 \pm 31.2$ & 0.47 \\
\hline Serum urea (mg/dL) & $62.5 \pm 6.8$ & $65.6 \pm 45.2$ & 0.69 \\
\hline Mortality (\%) & $15(10 \%)$ & $2(5 \%)$ & 0.32 \\
\hline
\end{tabular}

reduction in LV ejection fraction. The overall frequency of the GG genotype in HF patients was similar to that in the general population, implying then, not necessarily a causal relation, but presumably a differing adaptation to myocardial damage.

The association between CMA1 gene polymorphisms and heart disease, studied mainly in patients with hypertrophic cardiomyopathy ${ }^{18-20}$ has not been clear. To our knowledge, the present study is the first which demonstrates an association between CMA1 - 1903G/A polymorphism and LV systolic dysfunction. Proposed mechanisms include the possibility that the polymorphism, which is located in promoter of the CMA1 gene, alters protein expression, or if not functional, may be in linkage disequilibrium with other causative alleles. ${ }^{13}$ Effects of CMA1 polymorphism may be mediated through an acceleration of the remodeling process in patients with HF, and mainly in patients with nonischemic cardiomyopathy. Chymase is produced from mast cells and is not inhibited by angiotensinconverting enzyme inhibitors. ${ }^{21}$ In HF patients, mast cells increase in number in the failing myocardium, ${ }^{22}$ and may be implicated in ventricular dilatation and cardiac decompensation. ${ }^{23}$ 
These changes may be attributed to local angiotensin II activity, which induces hypertrophy of cardiac myocytes and myocardial fibrosis and therefore is the most important remodeling factor in the heart. ${ }^{24,25}$ Chymase may be responsible for the vast majority of production of local angiotensin II in the myocardium. ${ }^{4}$ In addition to the effects associated with direct angiotensin II production, chymase is associated with apoptosis; TGF- $\beta$ mediated fibrosis, ${ }^{26}$ collagen formation ${ }^{27}$ and fibroblast differentiation to myofibroblasts. ${ }^{6,23,28}$ Moreover, mast cell chymase produced in the myocardium can directly induce acute inflammation and affect tissue remodeling through activation of matrix metalloproteinases ${ }^{8}$ and IL- $1 \beta$ precursors, ${ }^{7}$ and stimulation of IL- 8 release resulting in recruitment of granulocytes. ${ }^{9}$ All of these are important features of the cardiac remodeling process, which may explain our finding of lower LV ejection fraction in patients with the CMA1 GG genotype. Of note, as per inclusion criteria, all our study patients had systolic heart failure $(\mathrm{EF}<40 \%)$, with a mean LVEF of $24 \pm$ $6.5 \%$. Thus, the absolute EF difference of four points in the CMA1 GG subgroup ( $25 \%$ vs. $21 \%$ ), actually reflects a $16 \%$ change when compared with the mean EF and is therefore statistically very significant $(P=0.005)$.

It is less clear why CMA1 polymorphism is associated with cardiomyopathy of nonischemic etiology. It may be related to the long-term impact of the remodeling process in systolic HF. In patients with ischemic etiology, it is not uncommon that HF symptoms start after initial extensive myocardial damage, although the remodeling process contributes little to the progression of HF. On the other hand, in nonischemic cardiomyopathy, the remodeling process may have greater importance and be linked more closely to the inflammatory process. In an animal model of viral myocarditis, there was an increased density of myocardial mast cells with a simultaneous up-regulation in gene expression of inflammatory cytokines and mouse mast cell protease- 5 (which is the counterpart of the human chymase), ${ }^{5}$ indicating that mast cell chymase both mediates and accelerates inflammatory pathways and is a crucial player in the remodeling process. Moreover, the myocardial remodeling phenomenon in HF progression may be the end point of several pathways, only some of which are mediated through cardiac angiotensin II formation. In nonischemic cardiomyopathy, the chymase-dependent remodeling process may be predominant, causing the observed reduced systolic function in our CMA1 GG patients.

We found our population frequency of the CMA1 $-1903 \mathrm{G} / \mathrm{A}$ genotype to be $53 \%$ and $47 \%$ for $\mathrm{A}$ and $\mathrm{G}$ alleles, respectively. This allele distribution showed a similarity to the respective frequencies reported in dbSNP using a white group ( $58 \%$ and $42 \%$ for the A and G alleles, respectively). Considerable interethnic variation in the frequencies of this polymorphism has been demonstrated, with the $-1903 \mathrm{G}$ allele being rarer in white populations compared with Afro-American, Chinese, and Japanese groups ( $18-20 \%$ and $80-82 \%$ for the A and $\mathrm{G}$ alleles, respectively, dbSNP), which is consistent with our findings.
We did not find a clinical association with the ACE I/D genotype in our HF patients. Although an association between ACE I/D polymorphism and cardiomyopathy was reported, ${ }^{29,30}$ other studies did not confirm such a relationship and in those which did the study cohorts deviated from the Hardy-Weinberg equilibrium..$^{13,31}$ Some authors suggested that although there was no causative relation between the ACE I/D polymorphism and cardiomyopathy, HF patients with the ACE DD genotype have poor outcome and increased mortality. ${ }^{14} \mathrm{We}$, as others, ${ }^{32}$ did not find such a correlation. Most of our patients were treated with pharmacotherapy involving modulation of the RAAS, including beta blocker, ACE inhibitor, and/or angiotensin II receptor blockers. More than a quarter were treated in addition with direct aldosterone antagonists. The clinical impact of the ACE I/D polymorphism may have been attenuated by these treatments, as demonstrated previously. ${ }^{14,33}$ Another explanation may be that ACE I/D genotype acts only in concert with other polymorphisms as a synergistic genetic polymorphism in order for its prognostic implications to become evident. ${ }^{15}$ Polymorphism in the chymase gene, less blunted by medical therapy, did have clinical implications and a lower LV ejection fraction in our patients.

\section{Limitations}

Several potential limitations need to be considered when interpreting the present findings. First, given that our patients were treated aggressively with anti-RAAS therapy, possible clinical implications of chymase and ACE genotypes might potentially be masked. Secondly, because the current study was not designed to explore a functional mechanism, our findings do not necessarily imply a causal relation, but presumably, a confounding effect, and further studies are needed to determine the importance of our findings in a larger sample of patients with dilated nonischemic cardiomyopathy.

\section{Clinical implications}

CMA1 promoter polymorphism was associated with patients (particularly with nonischemic etiology for HF) who had greater reduction in measured systolic LV function. In contrast, $A C E \mathrm{I} / \mathrm{D}$ polymorphism had no relation to the level of cardiac function. Although we report a single center experience with relatively small patient numbers, the findings were fairly robust by statistical analysis. The findings may explain differences in response to therapies aimed at modulation of the RAAS in patients with apparently similar HF profiles and treatments.

\section{ACKNOWLEDGMENTS}

Supported by the Research Authority of Zinman College.

\section{References}

1. Fedak PW, Verma S, Weisel RD, Li RK. Cardiac remodeling and failure: from molecules to man (Part I). Cardiovasc Pathol 2005;14:1-11.

2. Stolarz K, Staessen JA, Kawecka-Jaszcz K, et al. Genetic variation in CYP11B2 and AT1R influences heart rate variability conditional on sodium excretion. Hypertension 2004;44:156-162.

3. Urata H, Kinoshita A, Misono KS, Bumpus FM, Husain A. Identification of a highly 
Amir et al.

specific chymase as the major angiotensin II-forming enzyme in the human heart. J Biol Chem 1990;265:22348-22357.

4. Urata H, Boehm KD, Philip A, et al. Cellular localization and regional distribution of an angiotensin II-forming chymase in the heart. J Clin Invest 1993;91:1269-1281.

5. Kitaura-Inenaga K, Hara M, Higuchi K, et al. Gene expression of cardiac mast cell chymase and tryptase in a murine model of heart failure caused by viral myocarditis. Circ J 2003;67:881-884.

6. Hara M, Matsumori A, Ono K, et al. Mast cells cause apoptosis of cardiomyocytes and proliferation of other intramyocardial cells in vitro. Circulation 1999;100:1443-1449.

7. Mizutani H, Schechter N, Lazarus G, Black RA, Kupper TS. Rapid and specific conversion of precursor interleukin 1 beta (IL-1 beta) to an active IL-1 species by human mast cell chymase. J Exp Med 1991;174:821-825.

8. Lees M, Taylor DJ, Woolley DE. Mast cell proteinases activate precursor forms of collagenase and stromelysin, but not of gelatinases A and B. Eur J Biochem 1994;223: 171-177.

9. Huang C, Friend DS, Qiu WT, et al. Induction of a selective and persistent extravasation of neutrophils into the peritoneal cavity by tryptase mouse mast cell protease 6. J Immunol 1998;160:1910-1919.

10. Kittleson MM, Ye SQ, Irizarry RA, et al. Identification of a gene expression profile that differentiates between ischemic and nonischemic cardiomyopathy. Circulation 2004;110:3444-3451.

11. Rigat B, Hubert C, Alhenc-Gelas F, Cambien F, Corvol P, Soubrier F. An insertion/ deletion polymorphism in the angiotensin I-converting enzyme gene accounting for half the variance of serum enzyme levels. J Clin Invest 1990;86:1343-1346.

12. Danser AH, Schalekamp MA, Bax WA, et al. Angiotensin-converting enzyme in the human heart. Effect of the deletion/insertion polymorphism. Circulation 1995;92: 1387-1388.

13. Bleumink GS, Schut AF, Sturkenboom MC, et al. Genetic polymorphisms and heart failure. Genet Med 2004;6:465-474.

14. McNamara DM, Holubkov R, Janosko K, et al. Pharmacogenetic interactions between beta-blocker therapy and the angiotensin-converting enzyme deletion polymorphism in patients with congestive heart failure. Circulation 2001;103:1644-1648.

15. Andersson B, Blange I, Sylvén C. Angiotensin-II type 1 receptor gene polymorphism and long-term survival in patients with idiopathic congestive heart failure. Eur J Heart Fail 1999;1:363-369.

16. Sambrook J, Fritsch EF, Maniatis T. Molecular cloning. New York: Cold Spring Harbor, 1989;235-237.

17. Lindpaintner K, Pfeffer MA, Kreutz R, et al. A prospective evaluation of an angiotensin-converting-enzyme gene polymorphism and the risk of ischemic heart disease. N Engl J Med 1995;332:706-711.

18. Pfeufer A, Osterziel KJ, Urata $\mathrm{H}$, et al. Angiotensin-converting enzyme and heart chymase gene polymorphisms in hypertrophic cardiomyopathy. Am J Cardiol 1996; 78:362-364.
19. Pfeufer A, Busjahn A, Vergopoulos A, et al. Chymase gene locus is not associated with myocardial infarction and is not linked to heart size or blood pressure. Am J Cardiol 1998;82:979-981.

20. Fischer M, Lieb W, Marold D, et al. Lack of association of a 9 bp insertion/deletion polymorphism within the bradykinin 2 receptor gene with myocardial infarction. Clin Sci (Lond) 2004;107:505-511.

21. Guo C, Ju H, Leung D, Massaeli H, Shi M, Rabinovitch M. A novel vascular smooth muscle chymase is upregulated in hypertensive rats. J Clin Invest 2001;107:703-715.

22. Patella V, Marino I, Arbustini E, et al. Stem cell factor in mast cells and increased mast cell density in idiopathic and ischemic cardiomyopathy. Circulation 1998;97: 971-978.

23. Hara M, Ono K, Hwang MW, et al. Evidence for a role of mast cells in the evolution to congestive heart failure. J Exp Med 2002;195:375-381.

24. Serneri GG, Boddi M, Cecioni I, et al. Cardiac angiotensin II formation in the clinical course of heart failure and its relationship with left ventricular function. Circ Res 2001;88:961-968.

25. Chen LY, Li P, He Q, et al. Transgenic study of the function of chymase in heart remodeling. J Hypertens 2002;20:2047-2055.

26. Lindstedt KA, Wang $\mathrm{Y}$, Shiota $\mathrm{N}$, et al. Activation of paracrine TGF-betal signaling upon stimulation and degranulation of rat serosal mast cells: a novel function for chymase. Faseb J 2001;15:1377-1388.

27. Petrov VV, Fagard RH, Lijnen PJ. Stimulation of collagen production by transforming growth factor-betal during differentiation of cardiac fibroblasts to myofibroblasts. Hypertension 2002;39:258-263.

28. Matsumoto T, Wada A, Tsutamoto T, Ohnishi M, Isono T, Kinoshita M. Chymase inhibition prevents cardiac fibrosis and improves diastolic dysfunction in the progression of heart failure. Circulation 2003;107:2555-2558.

29. Raynolds MV, Bristow MR, Bush EW, et al. Angiotensin-converting enzyme DD genotype in patients with ischaemic or idiopathic dilated cardiomyopathy. Lance 1993;342:1073-1075.

30. Harn HJ, Chang CY, Ho LI, et al. Evidence that polymorphism of the angiotensin I converting enzyme gene may be related to idiopathic dilated cardiomyopathy in the Chinese population. Biochem Mol Biol Int 1995;35:1175-1181.

31. Tiret L, Mallet C, Poirier O, et al. Lack of association between polymorphisms of eight candidate genes and idiopathic dilated cardiomyopathy: the CARDIGENE study. J Am Coll Cardiol 2000;35:29-35.

32. Vancura V, Hubacek J, Malek I, et al. Does angiotensin-converting enzyme polymorphism influence the clinical manifestation and progression of heart failure in patients with dilated cardiomyopathy? Am J Cardiol 1999;83:461-462, A10.

33. McNamara DM, Holubkov R, Postava L, et al. Pharmacogenetic interactions between angiotensin-converting enzyme inhibitor therapy and the angiotensin-converting enzyme deletion polymorphism in patients with congestive heart failure. J Am Coll Cardiol 2004;44:2019-2026. 